\title{
Relationship between Cultural Distance and Pragmatic Comprehension
}

\author{
Vahid Rafieyan ${ }^{1}$, Maryam Sharafi-Nejad ${ }^{1}$, Zahra Khavari ${ }^{2}$, Ayoob Damavand ${ }^{1} \&$ Lin Siew Eng ${ }^{1}$ \\ ${ }^{1}$ School of Educational Studies, Universiti Sains Malaysia (USM), Malaysia \\ ${ }^{2}$ Payame Noor University, Qeshm International Branch, Iran \\ Correspondence: Vahid Rafieyan, School of Educational Studies, Universiti Sains Malaysia, 11800 Penang, \\ Malaysia. E-mail: honeyyear@yahoo.com
}

Received: November 18, 2013 Accepted: December 24, 2013 Online Published: January 6, 2014

doi:10.5539/elt.v7n2p103 URL: http://dx.doi.org/10.5539/elt.v7n2p103

\begin{abstract}
The distance between language learners' culture and the culture of the target language community is considered to play a crucial role in determining the level of pragmatic comprehension. In this respect, a study was conducted over 30 German students, perceived as culturally close to the British, and 30 South Korean students, perceived as culturally distant from the British, studying English as a Foreign Language at a university in their home countries. Pragmatic comprehension ability was assessed through a 24-item multiple choice pragmatic comprehension test. The findings suggested the crucial role of cultural distance in pragmatic comprehension ability, that is, a shorter distance from the culture of the target language community led to a higher level of pragmatic comprehension. The pedagogical implications of the findings suggested the provision of opportunities for the students of English as a Foreign Language to be exposed to the culture of the target language community through cultural instruction, educational sojourn, or telecollaborative partnership.
\end{abstract}

Keywords: cultural distance, pragmatic comprehension

\section{Introduction}

Culture, defined by the National Center for Cultural Competence as "integrated pattern of human behavior that includes thoughts, communications, languages, practices, beliefs, values, customs, courtesies, rituals, manners of interacting and roles, relationships and expected behaviors of a racial, ethnic, religious or social group; and the ability to transmit the above to succeeding generations" (Goode et al., 2000, p. 1), is an integral part of language. In fact, "a language is a part of a culture and a culture is part of a language; the two are intricately interwoven so that one cannot separate the two without losing the significance of either language or culture. The acquisition of a second language, except for specialized, instrumental acquisition, is also the acquisition of a second culture" (Brown, 1994, p. 165).

The significance of familiarity with and awareness of the cultural features of the target language for a language learner further arises when he or she realizes that "understanding the cultural context of language exchanges means knowing what is appropriate to say to whom, and in what situations, and it means understanding the beliefs and values represented by the various forms and usages of the language" (Peterson \& Coltrane, 2003, p. 2). Therefore, the reason for most communication failure is that the underlying norms and assumptions of the cultures the two speakers come from may differ remarkably (Ghobadi \& Fahim, 2009), that is, miscommunications are attributed to the lack of culture-specific pragmatic knowledge required in a circumstance (House, 2006).

Therefore, language learners whose cultural beliefs, norms, and perspectives have the most similarities with the cultural beliefs, norms, and perspectives of the target language speakers are supposed to better comprehend the culture-specific pragmatic knowledge of the target language expressions and texts and also to experience less communication failures in interactions with target language speakers than those language learners whose cultural beliefs, norms, and perspectives have the least similarities with the cultural beliefs, norms, and perspectives of the target language speakers. Considering this issue, the current study seeks to explore the role of cultural distance between the source and the target language communities in the language learners' level of pragmatic comprehension. 


\section{Literature Review}

\subsection{Hofstede's Dimensions of National Culture}

National cultural distance, defined as the extent to which the shared norms and values in one country differ from those in another, was presented by Hofstede (2001) in a model consisting of five dimensions including power distance, collectivism versus individualism, femininity versus masculinity, uncertainty avoidance, and Confucian dynamism or long-term versus short-term orientation in life.

Power distance refers to the extent to which the less powerful members of institutions within a country expect and accept that power is distributed unequally. Individualism, as opposed to collectivism, refers to societies in which ties between people are loose and people are not integrated into strong, cohesive groups. Masculinity, as opposed to femininity, refers to societies in which social gender roles are clearly distinct and do not overlap, that is, men are supposed to be assertive, tough, and focused on marital success whereas women are supposed to be modest, tender, and concerned with the quality of life. Uncertainty avoidance refers to the extent to which the members of a culture feel threatened by uncertain or unknown situations and try to avoid such situations. Confucian dynamism on long-term orientation pole refers to perseverance, ordering relationships by status, thrift, and having a sense of shame and on short-term orientation pole refers to personal steadiness and stability, protecting face, respect for tradition, and reciprocation of greetings, favors, and gifts.

\subsection{Cultural Distance}

In a study to examine the role of perceived cultural distance in the acculturation of exchange students in Russia, Galchenko and Van de Vijver (2007) selected a sample of exchange students from various countries studying at different universities in Moscow and divided them into two groups of Asians and Africans. The data were collected through a questionnaire measuring students' perceived cultural distance, home domain resources, personality, coping skills, acculturation orientations, psychological outcomes, and sociocultural outcomes. A large perceived cultural distance to the host culture was associated with more psychological problems and less sociocultural adaptation. The participants from Asian group reported the largest perceived cultural distance, the most neuroticism, the most stress, the least active coping strategies, and the least adjustment. In contrast, participants from the African countries showed a smaller perceived cultural distance with Russia, a lower level of neuroticism and stress, and a higher level of extraversion and seeking social support as a coping strategy.

Similarly, Suanet and Van de Vijver (2009) examined the role of perceived cultural distance in the adjustment of exchange students in Russia. The exchange students participating in the study were divided into four groups of African, Asian, Latin American, and former Soviet Union based on their cultural similarities. The data were collected through a questionnaire measuring students' perceived cultural distance, personality, coping skills, acculturation orientations, psychological outcomes, and behavioral outcomes. A large perceived cultural distance was associated with less psychological adjustment, more interaction with co-nationals, and less interactions with host-nationals. Asian students reported large perceived cultural distance, experienced more stress and homesickness, and socialized mostly with co-nationals, while students from former Soviet Union showed the smallest perceived cultural distance with Russia, less stress and homesickness, and more interaction with host-nationals.

\subsection{Pragmatic Comprehension}

A review of literature in the domain of inter-language pragmatics shows that studies on pragmatic comprehension, defined as the ability to recognize a mismatch between the literal utterance and the intention of the utterance (Taguchi, 2005), have dominantly focused on investigating the role of individual differences such as motivation (e.g. Rafieyan et al., 2013a), target language contact (e.g. Taguchi, 2008a), target language exposure (e.g. Taguchi, 2008b, 2011), and target language proficiency (e.g. Taguchi, 2008c, 2011) on the development of pragmatic comprehension.

Among recent studies, Rafieyan et al. (2013b) investigated the relationship between attitude toward incorporating target language culture into classroom instruction and the development of pragmatic comprehension over intermediate-level language learners at a language institute in Iran. The data were collected through an attitude questionnaire assessing language learners' attitudes and a pragmatic comprehension test assessing their development of pragmatic comprehension. The findings suggested a significantly positive relationship between attitude toward learning target language culture and pragmatic comprehension ability.

In another study, Rafieyan et al. (in press) explored the effect of telecollaboration on the development of pragmatic comprehension. Participants in the study consisted of two groups of undergraduate students of English as a Foreign Language at a university in Iran, one group paired with native American students through social 
networks whereas the other group was deprived from such a telecollaboration. The comparison of the performance of the two groups on the pragmatic comprehension test proved the significant positive effect of telecollaborative partnership on the development of pragmatic comprehension.

\section{Methodology}

\subsection{Participants}

Participants in the study consisted of two groups: 30 German junior undergraduate students of English as a Foreign Language (18 females and 12 males) studying at Universitat Freiburg in Germany and 30 South Korean junior undergraduate students of English as a Foreign Language (21 females and 9 males) studying at Yonsei University in South Korea. Besides the participants in the study, 2 native British speakers also participated in the study to provide the baseline data. The criterion for selection of German and South Korean students to participate in the study was based on the difference in the cultural distance between these countries and the Great Britain as the target language country. According to the survey data collected about the values of 50 countries around the world by Hofstede (2001), Germany was found to have a very close culture to the Great Britain whereas South Korea was found to have a very distant culture from the Great Britain. The national cultural distance between Germany and the Great Britain as well as South Korea and the Great Britain; according to the five dimensions of power distance, uncertainty avoidance, individualism/collectivism, masculinity/femininity, and long/short-term orientation; has been provided in table 1 .

Table 1. Index scores and ranks for national cultural distance

\begin{tabular}{lcccccccccc}
\hline \multirow{2}{*}{ Country } & \multicolumn{2}{c}{$\begin{array}{c}\text { Power } \\
\text { Distance }\end{array}$} & \multicolumn{2}{c}{$\begin{array}{c}\text { Uncertainty } \\
\text { Avoidance }\end{array}$} & \multicolumn{2}{c}{$\begin{array}{c}\text { Individualism/ } \\
\text { Collectivism }\end{array}$} & $\begin{array}{c}\text { Masculinity/ } \\
\text { Femininity }\end{array}$ & \multicolumn{2}{c}{$\begin{array}{c}\text { Long/Short-Term } \\
\text { Orientation }\end{array}$} \\
\cline { 2 - 13 } & Index & Rank & Index & Rank & Index & Rank & Index & Rank & Index & Rank \\
\hline Great Britain & 35 & $42-44$ & 35 & $47-48$ & 89 & 3 & 66 & $9-10$ & 25 & $28-29$ \\
Germany & 35 & $42-44$ & 65 & 29 & 67 & 15 & 66 & $9-10$ & 31 & $22-24$ \\
South Korea & 60 & $27-28$ & 85 & $16-17$ & 18 & 43 & 39 & 41 & 75 & 5 \\
\hline
\end{tabular}

Source: Hofstede (2001, p. 500)

\subsection{Instrument}

The instrument used for the study was a pragmatic listening comprehension test adopted from the test used in a previous study by Taguchi (2007). The pragmatic comprehension test consisted of 24 items based on a multiple choice design, with 4 options including one correct option and three distractors. For each item there was a dialogue between a male and a female native British speaker. The last sentence in each dialogue contained an implied opinion which was intended to test language learners' ability to comprehend the speaker's implied intention. Students had to listen to each dialogue and choose one of the four options provided which expressed the speaker's implied intention.

The validity of the pragmatic comprehension test was assessed through content analysis. The researchers wrote up the definition of what they wanted to measure and then gave this definition, along with the pragmatic comprehension test and a description of the intended sample, to two lecturers in the University of Tehran who were experts in the field of pragmatics. The lecturers confirmed that the content and format is consistent with the definition of the variable and the sample of objects to be measured. To assess the reliability of the pragmatic comprehension test, a pilot study was conducted over 20 junior undergraduate students of English as a Foreign Language at the University of Tehran in Iran. The reliability was assessed through Kurder-Richardson 21. The reliability coefficient of the pragmatic comprehension test was 0.82 .

To provide the baseline data, the pragmatic comprehension test was administered to the two native British participants. To check the level of agreement between the appropriate answers provided by them, the inter-rater reliability was assessed through Cohen's Kappa. The analysis of Cohen's Kappa would give a value between -1 and +1 . To interpret the values obtained by Cohen's Kappa, according to Landis and Koch (1977), values smaller than 0.00 show poor agreement between raters, values between 0.00 and 0.20 show slight agreement, values between 0.21 and 0.40 show fair agreement, values between 0.41 and 0.60 show moderate agreement, values between 0.61 and 0.80 show substantial agreement, and values between 0.81 and 1.00 show almost 
perfect agreement. The inter-rater reliability assessed for the pragmatic comprehension test was 1 which indicates perfect agreement between the two raters.

\subsection{Procedure}

At the beginning of the academic year 2013/2014 in September 2013, 30 copies of the pragmatic comprehension test were administered to German participants and 30 others were administered to South Korean participants by one of the staff members in the mentioned universities upon researchers' request. The participants were instructed to listen to the dialogues and check one of the four options which best determines the speaker's intended meaning. They then listened to the audio program twice to make sure their mistakes are due to pragmatic inefficiency not linguistic inefficiency. The test took around 30 minutes. Following the completion of the test, the answer sheets were collected and sent to the researchers to be analyzed.

\subsection{Data Analysis}

To determine language learners' performance on the pragmatic comprehension test, the sum of the answers were computed. Each correct answer was allocated 1 mark while no mark was allocated to wrong answers. As there were 24 items on the test, each student could get a mark of 0 to 24 . To determine the effect of cultural distance, the mean score for the marks obtained by each group was measured. Independent samples t-test was then used to compare the mean scores obtained by both groups. In this respect, a significance value of equal to 0.05 or less ( $p$ $\leq 0.05$ ) would indicate a significant difference between the mean scores obtained by the two groups whereas a significance value of above $0.05(\mathrm{p}>0.05)$ would indicate a non-significant difference between the mean scores obtained by the two groups (Pallant, 2013).

The significance value only indicates that whether the difference between the mean scores obtained by the two groups is significant or not. It does not show the size of the difference. To provide an indication of the magnitude of the difference between the two groups, the effect size was computed. There are a number of different effect size statistics. The most commonly used method of measuring effect size for independent-samples t-test is computing the percentage of variance accounted for, $r^{2}$ ( $r$ squared) (Gravetter \& Wallnau, 2013). $r^{2}$, in this study, measured how much of the variability in the scores could be explained by the cultural distance. The criteria for interpreting the value of $\mathrm{r}^{2}$, as proposed by Cohen (1988), are presented in table 2. All the analyses were performed using the Statistical Package for Social Sciences (SPSS) software, version 20.

Table 2. Percentage of variance explained, $\mathrm{r}^{2}$

\begin{tabular}{ll}
\hline$r^{2}=0.01$ & Small Effect \\
\hline$r^{2}=0.09$ & Medium Effect \\
\hline$r^{2}=0.25$ & Large Effect \\
\hline
\end{tabular}

\section{Results and Discussion}

\subsection{Results}

Table 3 presents descriptive statistics for the performance of German and South Korean students on the pragmatic comprehension test. Descriptive statistics consists of the number of students per group, the mean scores, the standard deviation, and the standard error of the mean. The most important statistic to be considered is the mean score. The mean score for the German students is 18.00 whereas the mean score for the South Korean students is 12.00 . As the mean scores indicate, generally German students had a better performance on the pragmatic comprehension test than the South Korean students. However, the mean score does not show whether the difference between the performance of the two groups is big enough to be considered significant or not. To be able to determine whether the difference between the mean scores is significant or not, the results of the t-test statistics need to be interpreted.

Table 3. Group statistics

\begin{tabular}{llcccc}
\hline & Group & N & Mean & Std. Deviation & Std. Error Mean \\
\hline Pragmatic & German Students & 30 & 18.00 & 2.45 & 0.45 \\
Comprehension Marks & South Korean Students & 30 & 12.00 & 2.94 & 0.54 \\
\hline
\end{tabular}


Before checking the significance value of the t-test, the assumption of equality of variation of scores for the two groups needs to be assessed. This is done, in SPSS, through Levene's test for equality of variances. A significance value of larger than $0.05(\mathrm{p}>0.05)$, for Levene's test, indicates the assumption of equality of variances has been met and the data presented for "Equal Variances Assumed" should be used to report the $\mathrm{t}$-value whereas a significant value of equal to 0.05 or less $(\mathrm{p} \leq 0.05)$ indicates that the variances for the two groups are not the same and the assumption of equal variance has been violated; thus, the data presented for "Equal Variances not Assumed" should be used (Pallant, 2013). In the current study; the significance level for Levene's test, as presented in table 4 , is 0.27 which is larger than the cut-off of 0.05 . This means that the assumption of equal variances has been met. Therefore, the data presented for "Equal Variances Assumed" is used to report the t-value.

Table 4. Independent samples test

\begin{tabular}{|c|c|c|c|c|c|c|c|c|c|c|}
\hline & & \multicolumn{2}{|c|}{$\begin{array}{l}\text { Levene's } \\
\text { Test for } \\
\text { Equality of } \\
\text { Variances }\end{array}$} & \multicolumn{7}{|c|}{ t-test for Equality of Means } \\
\hline & & \multirow[t]{2}{*}{$\mathrm{F}$} & \multirow[t]{2}{*}{ Sig. } & \multirow[t]{2}{*}{$\mathrm{t}$} & \multirow[t]{2}{*}{$\mathrm{df}$} & \multirow[t]{2}{*}{$\begin{array}{c}\text { Sig. } \\
\text { (2-tailed) }\end{array}$} & \multirow[t]{2}{*}{$\begin{array}{l}\text { Mean } \\
\text { Differ } \\
\text {-ence }\end{array}$} & \multirow{2}{*}{$\begin{array}{c}\text { Std. } \\
\text { Error } \\
\text { Differ } \\
\text {-ence }\end{array}$} & \multicolumn{2}{|c|}{$\begin{array}{l}95 \% \text { Confidence } \\
\text { Interval of the } \\
\text { Difference }\end{array}$} \\
\hline & & & & & & & & & Lower & Upper \\
\hline \multirow{2}{*}{$\begin{array}{l}\text { Pragmatic } \\
\text { Comprehen- } \\
\text { sion Marks }\end{array}$} & $\begin{array}{c}\text { Equal } \\
\text { Variances } \\
\text { Assumed }\end{array}$ & 1.23 & 0.27 & 8.60 & 58.00 & 0.00 & 6.00 & 0.70 & 4.60 & 7.40 \\
\hline & $\begin{array}{c}\text { Equal } \\
\text { Variances not } \\
\text { Assumed }\end{array}$ & & & 8.60 & 56.20 & 0.00 & 6.00 & 0.70 & 4.60 & 7.40 \\
\hline
\end{tabular}

To find out whether there is a significant difference between the performances of the two groups, the significance value, which is mentioned under the section labeled "t-test for Equality of Means", was used. The significance value assessed for the current study is 0.00 which is less than the cut-off of 0.05 . Therefore, there is a statistically significant difference in the mean pragmatic comprehension scores for German and South Korean students. To provide an indication of the magnitude of the difference between the two groups, the effect size was computed. The effect size computed through $\mathrm{r}^{2}$ for the size of difference between the mean scores obtained by German students and South Korean students in the current study is 0.56 which, according to the standard used to evaluate $\mathrm{r}^{2}$, indicates a very large effect size. Expressed as a percentage, 56 percent of the variance in pragmatic comprehension is explained by the cultural distance.

\subsection{Discussion}

The current study found that cultural distance is a major predictor of pragmatic comprehension. The closer the cultural beliefs, norms, and perspectives of language learners to the cultural beliefs, norms, and perspectives of the target language society; the higher the ability of language learners to comprehend target language pragmatically implied meanings. On the contrary, the further the cultural beliefs, norms, and perspectives of language learners from the cultural beliefs, norms, and perspectives of the target language society; the lower the ability of language learners to comprehend target language pragmatically implied meanings.

In the current study, German students of English as a Foreign Language whose cultural beliefs, norms, and perspectives, according to the findings obtained by the study conducted by Hofstede (2001), were very close to the cultural beliefs, norms, and perspectives of the British presented a significantly better pragmatic comprehension ability than South Korean students of English as a Foreign Language whose cultural beliefs, norms, and perspectives, according to the findings obtained by the study conducted by Hofstede (2001), were very far from the cultural beliefs, norms, and perspectives of the British.

Germans are geographically very close to the Great Britain and visit or are visited by the British more frequently than South Koreans who live thousands of miles away from the Great Britain. Consequently, they have much more opportunities to be exposed to the cultural features, culture-specific behaviors, and culture-specific 
expressions of the British than South Koreans. Besides, there are lots of common cultural norms which are shared by the societies within a region. These all have most probably contributed substantially to the higher target language pragmatic knowledge of Germans.

The findings of the study support the findings of the studies conducted by Bouton $(1992,1994)$ who found that comprehension of implicatures vary cross-culturally and that background and nationality of language learners affect comprehension of implicatures. In her studies; Korean, Japanese, and Chinese speakers showed significantly poorer performance on the comprehension of English implicatures than did German, Spanish, and Portuguese speakers. The findings of the study are also consistent with those obtained by Galchenko and Van de Vijver (2007) as well as Suanet and Van de Vijver (2009) who found that a large perceived cultural distance is associated with less sociocultural adaptation.

\section{Conclusion}

The current study found that cultural distance plays a significant role in determining the level of pragmatic comprehension. Language learners whose culture is perceived to be closer to the culture of the target language society have higher capability in comprehending target language pragmatically implied meanings than language learners whose culture is perceived to be distant from the culture of the target language society. In this study; German students of English as a Foreign Language, whose culture perceived to be very close to the British, showed higher ability in comprehending British culture-specific implicatures than South Korean students of English as a Foreign Language, whose culture perceived to be very distant from the British.

These findings point out the significant role of familiarity with and awareness of the cultural features of the target language society in bridging the cultural gap between the source and the target language societies which consequently contribute to the development of pragmatic comprehension. Therefore, opportunities should be provided for students of English in foreign language contexts to be exposed to the cultural features of the target language society through pragmatic instruction (Rafieyan et al., 2013a; 2013b; 2013c), educational sojourn (Rafieyan et al., 2014), or telecollaboration (Rafieyan et al., in press).

\section{Acknowledgements}

This research paper is dedicated to Khadijeh Mojaddam who aspired the research team's prosperity.

\section{References}

Bouton, L. F. (1992). The Interpretation of Implicature in English NNS: Does It Come Automatically Without Being Explicitly Taught? In L. F. Bouton, \& Y. Kachru (Eds.), Pragmatics and Language Learning (Vol. 3, pp. 53-65). Urbana-Champaign, IL: University of Illinois at Urbana-Champaign.

Bouton, L. F. (1994). Can NNS Skill in Interpreting Implicature in American English Be Improved through Explicit Instruction? A Pilot Study. In L. F. Bouton, \& Y. Kachru (Eds.), Pragmatics and Language Learning (Vol. 5, pp. 88-109). Urbana-Champaign, IL: University of Illinois at Urbana-Champaign.

Brown, H. D. (1994). Principles of Language Learning and Teaching (3rd ed.). Englewood Cliffs, NJ: Prentice Hall Regents.

Cohen, J. (1988). Statistical Power Analysis for the Behavioral Sciences. Hillsdale, NJ: Lawrence Erlbaum Associates.

Galchenko, I., \& Van de Vijver, F. J. R. (2007). The Role of Perceived Cultural Distance in the Acculturation of Exchange Students in Russia. International Journal of Intercultural Relations, 31(2), 181-197. http://dx.doi.org/10.1016/j.ijintrel.2006.03.004

Ghobadi, A., \& Fahim, M. (2009). The Effect of Explicit Teaching of English “Thanking Formulas" on Iranian EFL Intermediate Level Students at English Language Institutes. System, 37(3), 526-537. http://dx.doi.org/j.system.2009.02.010

Goode, T., Sockalingam, S., Brown, M., \& Jones, W. (2000). A Planner's Guide ... Infusing Principles, Content and Themes Related to Cultural and Linguistic Competence into Meetings and Conferences. Washington, DC: Georgetown University Center for Child and Human Development, National Center for Cultural Competence. Retrieved from www.georgetown.edu/research/gucdc/nccc/ncccplannersguide.html

Gravetter, F. J., \& Wallnau, L. B. (2013). Statistics for the Behavioral Sciences (9th ed.). Belmont, C A: Wadsworth Publishing.

Hofstede, G. (2001). Culture's Consequences: Comparing Values, Behaviors, Institutions and Organizations across Nations. Thousand Oaks, CA: Sage Publications. 
House, J. (2006). Text and Context in Translation. Journal of Pragmatics, 38(3), $323-337$. http://dx.doi.org/10.1016/j.pragma.2005.06.021

Landis, J. R., \& Koch, G. G. (1977). The Measurement of Observer Agreement for Categorical Data. Biometrics, 33(1), 159-174.

Pallant, J. (2013). SPSS Survival Manual: A Step by Step Guide to Data Analysis Using SPSS Program (5th ed.). Australia: Allen \& Unwin.

Peterson, E., \& Coltrane, B. (2003). Culture in Second Language Teaching [Online Resources: Digests]. Washington, DC: Centre for Applied Linguistics. Retrieved from http://www.cal.org/resources/digest/0309peterson.html

Rafieyan, V., Lin, S. E., \& Abdul-Rashid, M. (2013a). The Effect of Integrative Attitude on the Development of Pragmatic Comprehension. Elixir Social Studies, 57, 14041-14045.

Rafieyan, V., Norazman, A. M., \& Lin, S. E. (2013b). Relationship between Attitude toward Target Language Culture Instruction and Pragmatic Comprehension Development. English Language Teaching, 6(8), 125-132. http://dx.doi.org/10.5539/elt.v6n8p125

Rafieyan, V., Lin, S. E., \& Abdul-Rashid, M. (2013c). Language Learners’ Attitudes towards the Incorporation of Target Language Culture into Foreign Language Instructions. International Journal of Linguistics, 5(4), 169-177. http://dx.doi.org/10.5296/ijl.v5i4.4193

Rafieyan, V., Orang, M., Bijami, M., Sharafi-Nejad, M., \& Lin, S. E. (2014). Language Learners' Acculturation Attitudes. English Language Teaching, 7(1), 114-119. http://dx.doi.org/10.5539/elt.v7n1p114

Rafieyan, V., Sharafi-Nejad, M., Khavari, Z., Lin, S. E., \& Abdul-Rashid, M. (in press). Pragmatic Comprehension Development through Telecollaboration. English Language Teaching, 7(2).

Suanet, I., \& Van de Vijver, F. J. R. (2009). Perceived Cultural Distance and Acculturation among Exchange Students in Russia. Journal of Community and Applied Social Psychology, 19(3), 182-197. http://dx.doi.org/10.1002/casp.989

Taguchi, N. (2005). Comprehending Input Meaning in English as a Foreign Language. The Modern Language Journal, 89(4), 543-562. http://dx.doi.org/10.1111/j.1540-4781.2005.00329.x

Taguchi, N. (2007). Development of Speed and Accuracy in Pragmatic Comprehension in English as a Foreign Language. TESOL Quarterly, 41(2), 313-338. http://dx.doi.org/10.1002/j.1545-7249.2007.tb00061.x

Taguchi, N. (2008a). Cognition, Language Contact, and the Development of Pragmatic Comprehension in a Study-Abroad Context. Language $\quad$ Learning, $38(1), \quad 31$. http://dx.doi.org/10.1111/j.1467-9922.2007.00434.x

Taguchi, N. (2008b). The Role of Learning Environment in the Development of Pragmatic Comprehension. A Comparison of Gains between EFL and ESL Learners. Studies in Second Language Acquisition, 30(4), 423-452. http://dx.doi.org/10+10170S0272263108080716

Taguchi, N. (2008c). Pragmatic Comprehension in Japanese as a Foreign Language. The Modern Language Journal, 92(4), 558-576. http://dx.doi.org/10.1111/j.1540-4781.2008.00787.x

Taguchi, N. (2011). The Effect of L2 Proficiency and Study Abroad Experience on Pragmatic Comprehension. Language Learning, 61(3), 904-939. http://dx.doi.org/10.1111/j.1467-9922.2011.00633.x

\section{Copyrights}

Copyright for this article is retained by the author(s), with first publication rights granted to the journal.

This is an open-access article distributed under the terms and conditions of the Creative Commons Attribution license (http://creativecommons.org/licenses/by/3.0/). 